in DETAIL

Housing for People
of All Ages

flexible

unrestricted

senior-friendly

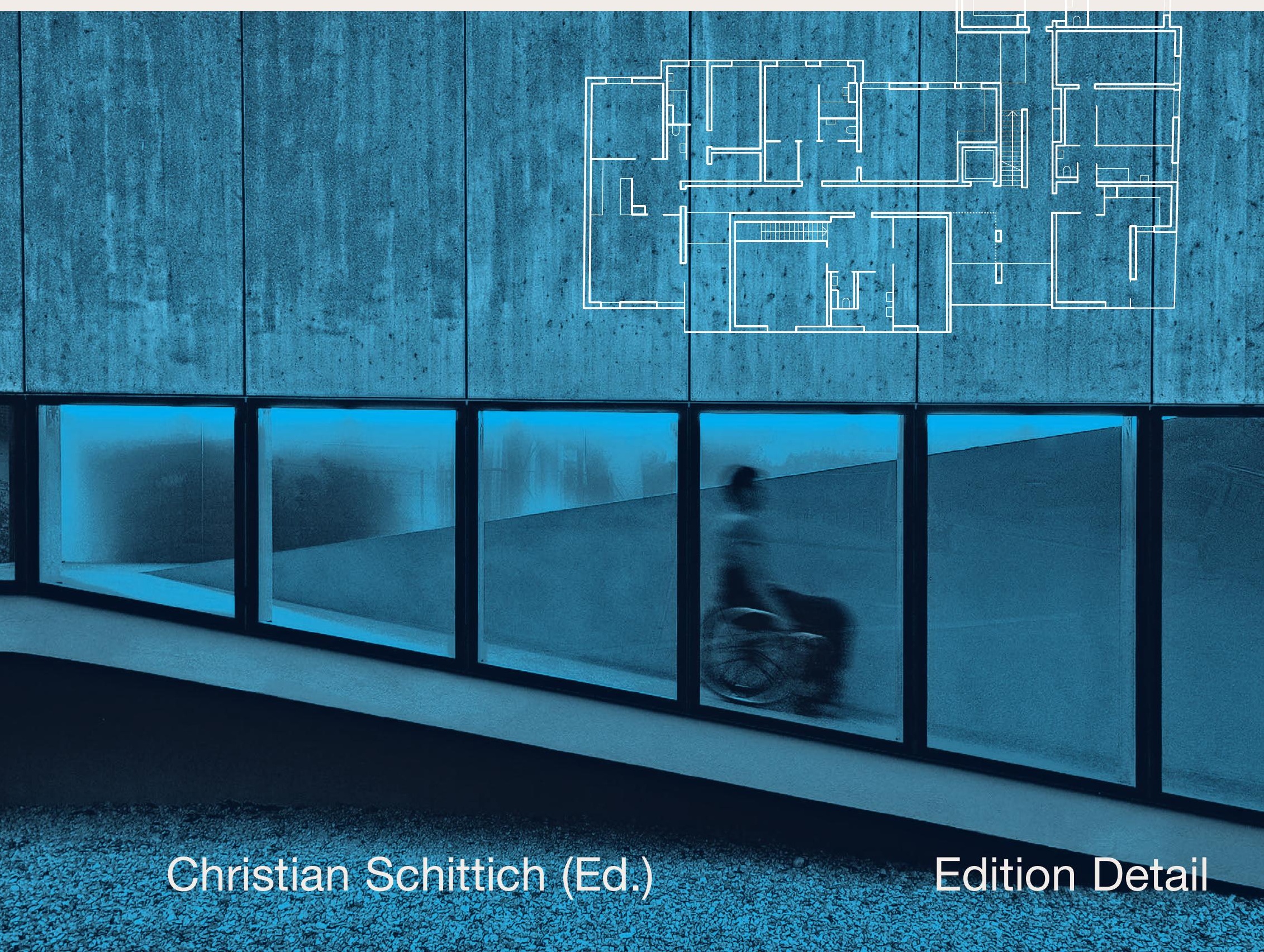



in DETAIL Housing for People of All Ages 



\section{in DETAI}

\section{Housing for People of All Ages}

flexible · unrestricted · senior-friendly

\section{Christian Schittich (Ed.)}

with essays contributed by

Peter Ebner

Joachim Giessler

Lothar Marx

Eckhard Feddersen and Insa Lüdtke 
Editor: Christian Schittich

Editorial services: Alexander Felix, Astrid Donnert, Michaela Linder

Melanie Schmid, Cosima Strobl, Andrea Wiegelmann

Translation German/English:

Catherine Anderle-Neill (pp. 26-143, 166-176)

Susan Richter (pp. 9-23, 145-165)

Drawings: Nicola Kollmann, Marion Griese, Daniel Hajduk,

Martin Hemmel, Caroline Hörger, Claudia Hupfloher, Elisabeth Krammer,

Cathrin Peters-Rentschler, Andrea Saiko

DTP: Peter Gensmantel, Andrea Linke, Roswitha Siegler, Simone Soesters

A specialist publication from Redaktion DETAIL

This book is a cooperation between

DETAIL - Review of Architecture and

Birkhäuser - Publishers for Architecture

Library of Congress Control Number: 2007927593

Bibliographic information published by the German National Library

The German National Library lists this publication in the Deutsche

Nationalbibliografie; detailed bibliographic data is available on the Internet at

$<$ http://dnb.d-nb.de>.

This book is also available in a German language edition

(ISBN: 978-3-7643-8118-9).

๑ 2007 Institut für internationale Architektur-Dokumentation GmbH \& Co. KG,

P. O. Box 3306 60, D-80066 Munich, Germany and

Birkhäuser Verlag AG, Basel · Boston · Berlin, P. O. Box 133, CH-4010 Basel,

Switzerland

This work is subject to copyright. All rights are reserved, whether the whole or part of the material is concerned, specifically the rights of translation, reprinting, re-use of illustrations, recitation, broadcasting, reproduction on microfilms or in other ways, and storage in data banks. For any kind of use, permission of the copyright owner must be obtained.

Printed on acid-free paper produced from chlorine-free pulp (TCF $\infty)$

Printed in Germany

Reproduction:

Martin Härtl OHG, München

Printing and binding:

Kösel GmbH \& Co. KG, Altusried-Krugzell

ISBN: 978-3-7643-8119-6

987654321 